\title{
9. 化学・生化学の研究
}

\section{§1. まえがき}

1982 年までの化学・生化学の研究をみると, 初期の 研究は水産物の製造・加工に直接関連したもので，材料 はほとんどが漁獲後しばらく経た鮮度の低下したもので あった。流通技術が発達していなかったことも大きな要 因と考えられる。その後, 徐々に鮮度のよいもの, さら には生きた状態の試料についての研究が行われるように なったが，分析技術の限界もあり，現在からみると物質 の動的な側面は捉えきれていないことは否めない。その 中でも多くの成果が得られ, 1983 年以降の研究の進展 の礎となった。

第二次世界大戦後から 1982 年までの研究は，次のよ うに概説される。タンパク質に関する研究はかまぼこの ゲル形成の解明を目的としたものが多く，坐り，戻りな どに関するものが初期に行われた。その後, イ力とコイ のアクトミオシンに関する基礎的な研究が始まり, 血合 肉も取り上げられた。さらに，魚肉タンパク質の $60 \%$ 以上を，筋原繊維を構成するタンパク質が占め，この筋 原繊維タンパク質がかまぼこその他の食品素材として利 用されることから，主要構成タンパク質のミオシン，ア クチン, トロポミオシン, トロポニンなどの精製の研究 が行われるようになった。一方, 結合組織を構成する筋 基質タンパク質についての研究も盛んに行われ, 主要成 分のコラーダンについてはアミノ酸組成, 熱安定性など が調べられた。

脂質についてみると, クジラも含めて脂肪酸組成の報 告が多い。また, 魚介類の油脂は高度不飽和脂肪酸を多 く含み容易に酸化することから, その機構の解明と酸化 油脂の栄養的側面の問題が研究された。一方, 脂溶性の ビタミンAについての報告も多い。さらに，魚類と甲 殸類の表皮抢よび筋肉中に存在する脂溶性の色素力ロテ ノイドについては, サケ類のアスタキサンチン, 海産魚 に多いツナキサンチンなどの同定が行われた。な抢，筋 肉色素ミオグロビンはタンパク質であるが，マグロの肉 色に関係することから基礎的な研究も多く行われた。

エキ又成分は魚介類の呈味に関係することから，この 方面の研究も活発に行われたが, 遊離アミ/酸, ヌクレ オチド，低分子ペプチド拉よび有機酸の分析が主流であ った。新規ペプチドの単離も行われた。

生物毒に関する研究の基礎はこの頃既に固められ, 麻 痺性貝毒の主要成分 saxitoxin とフグ毒 tetrodotoxinの 分布，動態などが調べられた。をた，環形動物イソメか ら nereistoxin が単離され, 農業用殺虫剤に実用化され
たことは特筆に值する。現在, 盛んな生理活性物質の研 究はこれらの実績に源をみることができる。

海藻については, 寒天の主要成分であるアガロース, アガロペクチンのほか，アルギン酸の構成糖などの研究 が行われた。また，海藻の遊離了ミノ酸，ペプチド，又 クレオチドおよびチトクロムの報告も多い。海藻独特の 色素であるフィコエリトリンなどの研究も行われた。

以上の上うな研究の背景の下に, 1983 年頃からは生 きた材料を主体とし，生体成分老対象とした分子レベル のダイナミックな研究が行われるようになった。その大 きな原動力となったものは活きた試料や高鮮度の試料の 入手が簡単になったこととともに，分析機器の発详があ げられる。例えば, 海洋の未利用資源を対象とし, 従来 からの食料資源としての海洋生物にとらわれない生理活 性物質研究が大きく進展したが，その基礎には核磁気共 鳴装置 (NMR), 質量分析計 (MS) などの分析機器の 発達上高速液体クロマトグラフ (HPLC) の普及があっ た。また，エキス成分の研究に打いては高速自動アミ， 酸分析計，さらにタンパク質の分野に执いては示差走査 熱量計, 円二色性测定装置, プロティンシーケンサの改 良と開発などがあげられる。また，脂質の分析に沶いて はガスクロマトグラフ (GC), MSに連結された GC/ MS 装置などがあげられる。一方，1990 年代になると 水産の化学分野でも遺伝子工学的技術が導入されるよう になった。魚介類タンパク質は一般に不安定で取り扱い にくかったが， cDNAクローニングにより一次構造が 容易に決定されるようになり, 機能の予測が簡単, 迅速 になった。以上のような科学技術の発展に伴い，1983 年以降の水産の化学と生化学の研究は大きく生命科学の 方向へ進んだ。

以下にタンパク質, 酵素, 脂質, エキ又成分, 色素, 生理活性物質, 海藻の化学成分のほか, 細胞生物学に関 連した項目を設けて, 1983 年から20 年間の化学と生化 学の研究の概要を述べる。な扔, 糖質については海藻の もの以外は研究報告が比較的少なく, その他の項で簡単 にふれた。また，臭いについてもまとまった報告が少な く，この章では脂質関連のものにとどめた。

(渡部終五)

\section{§2. タンパク質}

1982 年までのタンパク質に関する研究はかまぼこの ゲル形成の解明を目的としたものが多かった。その後, アクトミオシンに関する基礎的な研究が始まり，血合肉 も取り上げられた。さらに，魚肉タンパク質の60\%以 
上を占める筋原繊維タンパク質につき, 構成タンパク質 のミオシン, アクチン，トロポミオシン，トロポニンな どの精製が行われた。一方，結合組織を構成する筋基質 タンパク質についても，主要成分コラーゲンのアミノ酸 組成や熱安定性が調べられた。筋肉タンパク質にはその 活か，笳形質タンパク質に分類される水溶性タンパク質 画分があり，魚種による含量の違いが研究された。 1982 年以降の研究については以下, 管原繊維タンパク 質と結合組織タンパク質に分けて述べる。

\section{1 筋原繊維タンパク質}

1982 年頃までのタンパク質精製法の確立を受け，筋 原繊維の主要構成タンパク質のミオシン，アクチン，ト ロポミオシン，トロポニンなどについての生化学的・物 理化学的性状の解明々, 加熱抢よび凍結に伴う変性の機 構が分子レベルで行われたが，かまぼこにみられる魚肉 ゲル形成の分子機構の解明を目指したものが多かった。 このような研究の進展には，化学架橋剤と蛍光試薬の開 発, 抗体を用いた免疫化学的手法の適用, さらにはタン パク質の unfolding をみる示差走查熱量測定 (DSC), $\alpha$ らせんの含量を知ることのできる円二色性分析 (CD), タンパク質のゲル化をモニターする動的粘弾性測定，タ ンパク質のサブユニット構成を簡単に知ることができる SDS ゲル電気泳動分析などの技術が普及したほか，タ ンパク質の一次構造を容易に解明することができる遺伝 子工学的技術の導入が大きな役割を果たした。

まず魚類についてみると，ミオシンについては，普通 筋抢よび血合筋を含嗱種々の魚種から精製が行われ， サブュニット組成とATPase 活性が調べられた。魚類 ミオシン分子は分子量約 200,000 の重鎖 2 本と分子量 約 20,000 の軽鎖 4 本から構成されることが示されると ともに，軽鎖サブュニットの種特異性の解明が進めら れ，魚類の遊泳速度と分子量，等電点などとの関連が報 告された。一方，ミオシン分子はプロデアーゼの限定分 解により，ATP およびアクチン結合部位がありランダ ムコイルの割合が高い $\mathrm{N}$ 末端側のサブフラグメント -1 (S1) と $\alpha$ らせんが 2 本絡まりあって coiled-coil の繊維 状となっているC末端側のロッドが調製された。プロ テアーゼ分解によりロッドはさらにサブフラグメントー 2 (S2) とLーメロミオシン (LMM) に分けられるが， LMM の単離も進められた。また, S1 と S2 の結合した H一メロミオシン (HMM) の精製も行われれた。S1に ついては異なった軽鎖を結合したアイソフォームの精製 と, 軽鎖を異なった S1 重鎖に結合させたハイブリッド を調製して性状の变化をみることが検討された。一方， ロッドの機能はフィラメントを形成して S1でATP 分 解によって得られる化学的エネルギーを運動エネルギー として筋肉に伝えることにあるが，このフィラメント形
成能は魚類では一般に弱いこと，Mgイオンが重要であ ることなどが示された。

魚類ミオシンおよびそのサブフラグメント（S1， LMM など）の加熱変性と凍結変性について研究が行わ れた。従来のATPase残存活性を测定する方法の汪 か, 先述の化学修飾剂, 化学架橋剂, 蛍光試薬の使用, DSC, CD，動的粘弾性の測定，プロテアーゼに対する 消化性やゲルろ過パターンなどが検討された。その結 果, コイ・ミオシンの加熱変性に打いては $\mathrm{S} 1$ 機能の Ca-ATPase の失活に先んじてまずS2の凝集が始ま り, ロッドの変性へと進むことが示された。一方, 凍結 ではS1の変性が先に進むことが明らかとなった。スケ トウダラ・ミオシンの加熱ではロッドの変性より先に S1の変性が起こるなど, 魚種によって変性様式が異な ることが示された。一方, DSC およびCD 分析では低 温に生息する魚類ほど構造安定性に劣ることが示され た。このほか，ミオシンとアクチンが結合した状態の筋 原纎維とアクトミオシンの安定性が研究された。この場 合, 加熱や凍結に伴う変性上, 糖類の保護効果, 重合り ン酸塩, 低 $\mathrm{pH}$, 高塩濃度, 高压処理などの影響が検討 された。また，変性に伴うSS 結合によりミオシンが高 分子化することも示された。さらに，アクトミオシンの ゲル化に及ぼすトロポミオシンおよび無脊椎動物筋肉に 特徎的な筋原繊維タンパク質のパラミオシンの影響が調 ベられた。

1990 年代に入ると魚類筋肉タンパク質にも遺伝子工 学的手法が導入され研究の様相が一変した。従来から研 究実績の多かったコイのミオシン执よびアクチンで進展 したが，その後はトロポミオシンなどでも同様な研究が 進められた。

コイは生息温度の違いによってATPase 活性抢よび 熱安定性の異なるミオシン・アイソフォームが発現する ことが示され，ミオシンの構造と機能あるいは熱安定性 の関係を探るよいモデルとしての可能性が示された。そ こで，ミオシン重鎖抢よび軽鎖の全てがクローニングさ れ，一次構造が決定された。さらに大腸菌あるいは粘菌 組換え DNA 体を用いたリコンビナント・タンパク質, キメラ体，アミノ酸の点変異体などの人為的タンパク質 の改変が適用され種々の解析が行われた。最近では産業 上重要なスケトウダラ, シログチ, シロザケ，カンパチ のほか，ドチザメなどのミオシン重鎖の一次構造が相次 いで報告されている。軽鎖についてはさらに多くの魚種 について cDNAクローニングが行われたが，先の構造 と魚類の遊泳運動に関係した特徵が裏付けられた。す シンの一次構造と構造安定性との関係については先述の コイ，スケトウダラのほか，体内に多量の尿素を含む海 産サメ類についても行われた。なた，コイの温度適応に 関連して，低温馴化したコイの死後硬直の進行が高温馴 
化したものに比べて遅くなること，その原因が低温馴化 により筋小胞体の Ca-ATPase，いわゆるCa ポンプの 活性が上昇するためであることが示されだ。

一方，魚類のアクチンとトロポミオシンについても一 次構造が解析され，アクチンに関してはその構造が哺乳 類のものと酷似するものの, ATP 結合部位周辺にアミ ノ酸変異がみつかり，魚類アクチンの熱安定性の低さお よびATP 結合の弱さとの関連が報告された。トロポミ オシンについては先述の LMM と同様に， $\alpha$ らせんの 2 重コイル構造の特徵が示された。後述する海産無梢椎動 物のトロポニンの解析とは異なり，わが国では魚類トロ ポニンの一次構造解析は行わ扎ていない。なお， $\alpha$ アク チニン，コネクチンおよびパルブアルブミンに関しても 性状が調べられた。

海産無脊椎動物のミオシンでは軽鎖が筋収縮の Ca 制 御に直接関係するため，異なるミオシンの軽鎖に入れ換 えたハイブリッド・ミオシンを用いた研究が二枚貝のア カザラガイを中心に行われた。軟体動物ではミオシン側 のCa制御のほかに，アクチン・フィラメント側にも $\mathrm{Ca}$ 調節機構があり，これにはトロポニン (Tn) とトロ ポミオシンが関係する。アカザラガイでは, アクトミオ シンのATPase 活性を阻害する TnI サブュニットが脊 椎動物のものとは異なり，2つのアイソフォームからな ることが示された。なた，Ca と結合する TnCサブユニ ットは脊椎動物のものでは 4 つの Ca 結合サイトをもつ が，アカザラガイのそれは $\mathrm{C}$ 末端側の 1 つしか認めら れず，大きく異なった。アカザラガイの両サブュニット ともクローニングされてリコンビナント・タンパク質を 用いた機能解析が詳細に行われた。トロポニンのサブユ ニットの解析はこのほか，ホタテガイでも行われた。

また，スルメイカについてはミオシン，アクチンおよ び筋原䋐維の加熱変性と $\mathrm{Ca}$ の影響が解析された。卜ロ ポミオシンも一次構造がムラサキイガイ前足率引䈘 (ABRM) とアカザラガイ閉款筋のものについて報告さ れたが，魚類のものと大差なかった。卜ロポミオシンに ついては, マガキのアレルゲンとしての観点からも研究 が行われた。さらに ABRMでは無脊椎動物の筋肉に特 徵的な筋収縮, すなわち, 低工ネルギ一消費の長時間収 縮を行うキャッチ筋に多量に含まれるパラミオシンの一 次構造が明らかになった。また，このキャッチ収縮を制 御する弾性タンパク質トゥイッチンが ABRM で発見さ れ, 本タンパク質のリン酸化により，キャッチ収縮が解 除されることが示された。無脊椎動物ではこのほか，ウ バガイからアクチン結合タンパク質, マダコとホタテガ イ外套膜からミオシン，スルメイカから ン，クルマエビからトロポニン，エゾアワビからトロポ ミオシンが単離されて性状が調べられた。エゾアワビの ミオシン軽鎖は一次構造が決定された。また，スサビ，
リと不稔性アオサの海藻からはアクチンがクローニング された。

\section{2 結合組織タンパク質}

1982 年までにコラーゲンについては魚類および海産 無脊椎動物を問わず多くの研究が行われたが，1983年 以降も引続き精力的な研究がなされた。すなわち，魚類 ではコラーゲンの体内分布が詳細に調ベられた。また， コラーゲン分布と魚類の遊泳運動の関係が明らかにさ れ，筋肉や皮膚の主要成分であるI 型コラーゲンのほ か，V型コラーゲンの重要性も認識された。対象は，将 ケI 型コラーゲン，サメ・コラーゲン，肺魚真皮 I 型コ ラーゲン，ニジマス酸可溶性コラーゲン，ニジマス V 型 コラーゲン，サケ頭骸軟骨【型扝よびX型コラーゲン， キダイとマアジの筋肉，皮角のコラーダン，ブリ V 型コ ラーゲン，コモンカスベ筋肉コラーゲンなどである。注 目されるのはV 型コラーゲンと魚肉貯蔵中の肉質軟化と の関倸である。魚類の肉質は死後急激に軟化するが，こ の変化にV型コラーゲンが関係することが示唆された。 なお，コラーゲンの関連タンパク質のエラストイジンが サメ鯺から単離された。

一方，1996 年になるとコラーゲンについても cDNA クローニングの手法が導入された。最初に試みられたも のはニジマス I 型コラーゲンである。最終的には $\alpha 1$, $\alpha 2, \alpha 3 の 3$ 種類の $\alpha$ 鎖の一次構造が決定された。その 後, マダイ I 型コラーダン $\alpha 1$ 鎖および $\mathrm{V} / \mathrm{X}$ 型コラー ゲン $\alpha 1$ 鎖のクローニングが行われた。電気泳動分析の みに頼っていた魚類コラーゲンの鎖組成の実態が明確に なるとともに，魚類コラーゲンの特徵が一次構造レベル で明らかになった。

魚肉の死後の軟化に関連して, ニジマスのI型を $\mathrm{V}$ 型 コラーゲンを分解するマトリックスメタロプロテアーゼ のクローニングも行われた。同種の分解酵素はコイ培養 細胞からもクローニングされた。さらに，アユを対象に コラーゲン分解酵素の一つであるゼラチナ一ゼの季節変 化も調ベられた。また，細胞外マトリックスに関連して コラーゲンなどを認識して細胞接着などに大きな役割を 果たすフィブロネクチンの研究もコイ，ナマズおよびヒ ラメのものについて行われた。

海産無脊椎動物コラーゲンについては，クラゲ，クル マエビ，ナンキョクオキアミなどの甲殼類の筋肉，スル メイカ外套膜と筋肉, ヒトデ体壁, ウ二壳, アコヤガイ など二枚貝の閉殼筋と外套膜, ナマコ体壁, 原索動物の ホヤ筋膜体などの分子種についての研究が行われた。無 脊椎動物のコラーゲン分子は魚類とは異なり，大きな種 特異性を示して複雑であることが示された。なお，クロ アワビI 型コラーゲンでは cDNAクローニングが行わ れ，2 種類の $\alpha$ 鎖の一次構造が決定された。アワビ類の コラーゲン含量は季節変化を示し, 対応して筋肉の硬さ 
も季節変化することが示された。また，サザエやアワビ などの巻貝の可食部は加熱に伴って著しく柔らかくなる が，これがコラーゲンのゼラチン化によることが示され た。

結合組織に関連したタンパク質として，魚類の耳石か らコラーゲン様タンパク質, アカフジッボからセメント タンパク質，ムラサキイガイから接着タンパク質と足系 タンパク質, 造礁サンゴからミニコラーゲン, などがク ローニングされている。

このような研究の経緯の中で, 日本水産学会の大会に おいて多くの関連するシンポジウムとミニシンポジウム が開催された。

（渡部終五）

\section{§3. 脂 質}

水産脂質研究の発展は, 分析機器の性能向上と決して 無縁ではない。GC用のキャピラリーカラムは 1980 年 代初頭に実用化され，脂肪酸などの脂質成分の分析精度 をそれまで汎用されてきた充填力ラムに比べて格段に向 上させた。その結果，分析が難しかった脂肪酸位置異性 体の分離分析が可能となった。アジ，ブリ，マダイ，ア ユ，ギンザケ，トラフグなどの組織抢よび卵などについ て, 天然魚と養殖魚の脂肪酸と脂質組成の詳細な比較研 究が行われている.さらに，微量脂質成分の分析も可能 となり, サケ精巣脂質のフラン酸, マボヤ脂質の n-3 系高度不飽和脂肪酸, 海綿の demosponjic acidなどの 微量脂質成分の含量が報告されるようになった。さら に，長鎖高度不飽和脂肪酸も海産動物組織脂質中に見出 されるようになった。このほかにも，中性抢よび極性プ ラスマローゲンの構成脂肪酸と炭化水素鎖の位置異性体 の組成分析が行なわれるようになり, サメ類とイ力類肝 臓のジアシルグリセリルエーテルおよびサメ類, マダ ラ, カツオなどの魚類笳肉抢よびマガキ, ホヤなどの海 産無冷椎動物組織中のプラスマローゲンの詳細な脂肪鎖 組成が明らかにされている。一方, HPLC用の分析力 ラムは様々な分析モードでの理論段数が格段に改善され て脂質研究に供されるようになり，GCでは分析できな かった難揮発性脂質の精密分析が可能となった。とく に，海産魚類トリグリセリドとグリセロリン脂質は，工 イコサペンタエン酸（EPA）やドコサヘキサエン酸 (DHA) などの水産脂質に特有の高度不飽和脂肪酸の組 成比が高いために分子種の相互分離が困難であったが， 分離力ラムの性能向上に伴ってマイワシのトリグリセリ ドとタラ類の筋肉リン脂質のかなり詳細な分子種分析が できるようになった。さらに，化学的誘導体化と組み合 わせた分析手法により，トリグリセリドの DHA 結合部 位の特定とトリグリセリドの光学異性体分子種の相違を 明らかにすることも可能となった。一方，1990年代に は MSはGCのみならず HPLC 用の検出器としても広
く利用されるようになり，NMR と組み合わせてナガ二 シと海綿類に新規カロテノイド抢よびブラックバスの新 規アポカロテノイドが見出されている。また，高温耐性 の中極性キャピラリーカラムを用いた GC/MSによる 魚類グリセロリン脂質の分子種分析も試みられている。 さらに，薄層クロマトグラフィー（TLC）用の多様な 分離モードのプレートが市販され，1980年代には容易 に手に入れることができるようになった。また，TLC に水素炎イオン化検出器を装備した分析装置（TLCFID）が 1980 年代に市販されると，デンシトメトリー に代わって脂質の定量分析に広く用いられるようにな り，マダラ筋肉などに微量存在するジアシルグリセリル エーテルの定量などが可能となった。1990 年代には， 試料の非破壊成分分析が行われるようになり，魚肉中の 脂質の定量にフーリ工変換赤外分光法 (FTIR) が用い られたほか，脂質酸化度の測定をNMRで行うなどの分 析法も報告された。

脂質生化学の分野もこの20 年間に目覚しい発展を遂 げた。1975 年にデンマークの Dyerberg とBangによっ て発表されたデンマーク領グリーンランドに居住するイ 又イットとデンマーク本土に居住する人々を対象とした 疫学的調查結果が端緒となり，ヒトに対する水産油脂の 生理作用に関する脂質生化学的な研究がわが国でも盛ん に行われるようになった。虚血性心疾患の発症は遺伝性 ではなく，イヌイットが常食している魚類とオットセイ に由来するの EPA が発症抑制に関与していることが証 明されたことから，EPAに関する実に多様な研究がな されてきた。

1980 年代には, EPA の示す血清脂質低下作用と抗動 脈硬化作用をはじめとする多様な生理作用が内外に広く 認められるようになり，医家用 $\mathrm{EPA}$ 製剂がわが国で開 発されている。また， $\mathrm{n}-3$ 系脂肪酸の補助食品として， トリグリセリドを主成分とする精製魚油力プセルが内外 で流通するようになった。1980年代には EPAはイワ シなどの多穫性赤身魚から抽出されていた。したがっ て，ケイ酸カラムを応用した EPA 含有トリグリセリド の精製などの，EPAの大量精製法に関する研究が行わ れた時期があった。また，リパーゼによるエステル交換 によりトリグリセリド中の EPA 含量比を増大させる研 究も多く行われている。その後, 海洋細菌の中に EPA 産生菌が見出され，1990年代には微生物による EPA， DHA などの $\mathrm{n}-3$ 系高度不飽和脂肪酸の生産に関する研 究が隆盛を極めた。一方, 1980 年代後半には水産油脂 中の DHA が示す生理作用が注目されるようになった。 脂質代謝に及ぼす影響, 癌抑制作用など多様な生理作用 が研究されてきたが，とくに乳幼児の網膜機能の発達に はDHAの摂取が効果的であることが認められ，1990 年代後半には DHA 強化乳児用粉ミルクが市場に出るよ 
うになった。この他, 精製魚油あるいはDHA を含む構 造脂質を添加することによってDHA 含量比を高めた多 様な加工食品が市場に出回るようになった。これに伴 い，ホスホリパーゼ $\mathrm{A}_{2}$ によるエステル交換を利用した $\mathrm{EPA}$ ・DHA 含有グリセリドの合成がなされ，EPA・ DHA 含有グリセロリン脂質を取り込んだ赤血球の流動 性, n-3 高度不飽和脂肪酸含有ホスファチジルコリンの 細胞分化誘導作用に及ぼす影響などが報告されている。 また，海藻脂質には抗腫瘍活性が報告されている。その 後に DHA 産生菌が見出され, n-3 系高度不飽和脂肪酸 の供給源は微生物にとって代わられつつある。

前述のように, 1970 年代をでは水産脂質の研究は組 成分析が主であったが，1980年代以降，水産生物の脂 質代謝に関する研究はヒトに扔沙研究と同様に, 生理 機能に焦点をあてたものが増えてきた。コイ腸管での脂 質生合成，コイ栓球に㧍けるプロスタグランジン合成な ぞの生化学的な基礎研究のほか, 過酸化脂質投与コイ血 漿リポタンパク質の脂質成分の変化, マダイへの酸化油 含有飼料投与の生体脂質過酸化への影響などの養殖現場 で問題となる魚類への飼料過酸化脂質投与の影響, 絶食 がコイ肝脺蔵における脂質生合成に及ぼす影響などの栄 養化学的見地からの研究もみられるようになった。 EPA とDHA に代表されるn-3 系高度不飽和脂肪酸 は，水産動物の䭒飼料成分としてもその有效性が確認さ れている。飼料としてのアルテミアと海産クロレラに対 する $\mathrm{EPA} の$ 強化, マダイ稚魚の DHA 要求量, ブリ稚 魚の n-3 高度不飽和脂肪酸要求量, ソウギョの必須脂 肪酸要求など, 稚仔魚用飼料中の高度不飽和脂肪酸含量 に焦点を当てた研究がみられるようになった。こ㧈ら上 関連して，クルマエビとハマチの成長に及ぼす飼料脂質 の組成および要求量の影暜, エゾアワビやブリ稚魚用飼 料の $\mathrm{n}-3$ 高度不飽和脂肪酸要求量, 責殖マダイ飼料の トコフェロール要求量, クルマエビの食䬣性コレステ ロール要求, ヒラメ仔魚期のアルテミア中のビタミン $\mathrm{A}$ 要求量, クルマエビ体脂質成分（トリグリセリド, コレステロール）に及ぼす飼料りン脂質の影響などの， 魚類脂質栄養学の分野での研究が詳細に検討されるよう になった。養殖マダイの飼料トコフェロールが高度不飽 和脂肪酸含量の過酸化に与える影響などの研究にみられ るように, 1990 年代後半からは養殖魚の耐病性の向上 抢よび食品としての品質向上など，飼料に対する評価を これまでにない視点から見直す研究がみられるようにな った。

このように，水産油脂そのものはヒトのみならず魚類 に上っても生理的に有用な物質であるが，前述の EPA とDHAのような高度不飽和脂肪酸の組成比が高いので 容易に酸化しやすい点が，水産資源を利用・加工する上 で問題とされてきた。1980 年代半ば以降には, サバと
フナを原料とした馴れずし，いわし棣漬けなどの水産発 酵食品の製造中における，また塩干しいわし，塩ウ二， 加熱調理したマイワシおよびマサバ，煮干しいわしなど の加工食品の熟成・貯蔵中に抢ける脂質成分の变化が自 動酸化と酵素的加水分解の両面加検討さ㧈ている。さ らに，これらの原料となる生鮮魚介類の冷蔵冷凍中の脂 質成分の劣化，ならびに解凍・凍結処理が魚介類の脂質 成分に及ぼす影響が多くの原料魚介類について詳細に報 告されている。脂質成分の自動酸化之加水分解は，水産 食品の品質を低下させる場合が多い。すなわち，酸化脂 質分解物はマイワシの臭気成分のように一般には嫌われ る魚臭さの原因となることが，揮発性成分の分析から明 らかにされた。

さらに，不飽和脂質の酸化によって生成される一連の 過酸化物とそれらの分解物は，多くの場合，生理的に有 害であるこ上から，水産脂質の酸化防止に関する研究が 盛九に行われてきた。既知の合成抗酸化剂のほか，煮干 いわしのくん煙処理，フィッシュミール製造時に抢ける メイラード反応物質の生成, 魚油へのセサモール添加, タラ肝油への緑茶茶がら抽出物添加など, 様々な天然物 の示す水産脂質に対する酸化抑制効果が報告されている。 1990 年代後半からは酸化防止機構の解明を目的とした 食品モデル系を用いた研究がみられるようになり，それ までに多くの報告があったバルク油に加えてリン脂質り ポソーム, 遊離高度不飽和脂肪酸のミセル，魚油エマル ションなどの複合系における脂質酸化のメカニズムが詳 細に検討されるようになった。

一方，1980 年代には魚皮に抢いて脂質の選択的加水 分解が起こることがマイワシなどで報告された。その 後, アユ体表粘液にはリポキシゲナーゼ様酵素が存在 し，コイとマイワシで12-リポキシゲナ一ゼ産物が同定 された。さらに，魚類組織には基質位置特異性が高いリ ポキシゲナーゼが存在するとの研究報告が 1990 年代に 相次いだ。キュウリウオ，アユなどでは，独特の香りの 生成にこれらの脂質過酸化酵素が関与していることが明 らかにされた。さらに，くん煙成分，加ば焼香気成分， 焼き海苔香気などの一般に好をしい上される香気には， 加熱により生じた過酸化脂質分解物が一部関与する。こ のように，脂質酸化生成物は時として水産食品に好まし い香りを付与することがあることは興味深い。

1983 年から 2002 年までの 20 年間に, 日水誌抢よび Fish. Sci.に揭載された脂質に関連する報文は約 200 編 を数える。全揭載論文の約 $4 \%$ が脂質を取り扱った論 文ということになる。また，日本水産学会の大会におけ る脂質関連のシンポジウムは 1985 年に「水産動物の䇨 肉脂質」, 1993 年に「水産脂質一その特性と生理活性一」 の 2 回開催され，その時々の水産脂質に関する最新の 研究が紹介され，それぞれ水産学シリーズ 57 巻と 96 
巻として刊行されている。

水産脂質にヒ下に対する多様な生理機能がみつかって から，それまでは比較的地味であった脂質分野の研究は 一気に世間から注目されるようになった。研究の発展に 伴ってッールとしての分析手法と機器類が目覚しく発展 した 20 年間であった。その延長線上に今後の水産脂質 研究が行われていくとすれば，1）新たな生理機能の発 見に向けての脂質生化学的研究，2)高機能性脂質の大 量生産, 3)これまで以上に高性能の分析機器の開発と 応用，4）水産食品の安全・健全性々水産脂質の関わ り，などが今後大きな潮流となっていくであろう。

(大島敏明)

\section{§4. 含窒素低分子成分}

この 20 年間に打けるエキス成分の研究とそれ以前と の大きな相違は HPLCの普及により，遊離アミノ酸以 外の工キ又成分も分離定量が容易になったことである。 その結果, ヌクレオチド, イミダゾール化合物, オピン

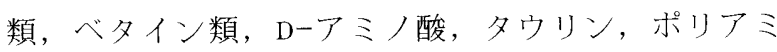
ソ，グアニジノ化合物などの HPLCによる分析法が開 発され，多くの魚介類に打汁るこれら化合物の分布が明 らかにされた。1989年には「魚介類のエキス成分」の シンポジウムが開催され，それまでの成果が集大成され ている。

さらに，この 20 年間の大きな変化はエキス成分の生 理的条件による変動, 生体内での代謝抢よび生理機能に 関する研究が広く行われてきたことである。オピン類で は新規オピンが無脊椎動物に発見され, 詳細な分布が調 べられ，嫌気最終産物としての機能も明らかにされてい る。オピンデヒドロゲナーゼ類についても, それらの性 質と系統発生との関連性が検討されている。魚類筋肉の イミダゾール化合物の分布が詳細に検討され，代謝抢よ び嫌気的運動に伴うプロトンの緩衝物質としての機能が 明らかにされている。タウリンに関してはその生合成経 路が給䬣抢よびトレーサー実験あるいは酵素学的側面か ら研究され，無寿椎動物の細胞内等浸透調節における機 能が調べられている。また, 前駆体の一つであるヒポタ ウリンがヨーロッパヒラガキから単離され，その他の無 亦椎動物と魚類にも検出されている。トリメチルアミン オキシドの生合成経路も検討され，デメチラーゼの性質 が調べられている。多くの無脊椎動物の遊離アミノ酸予 よびベタイン類の等浸透調節との関連性も調べられてい る。一方，10年ほど前からエビ・カ二類, 二枚貝, 頭

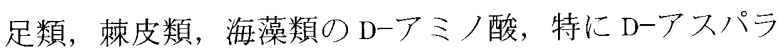
ギン酸とDーアラニンに関する検討が広く行われ，分析 法抢よび分布が明らかにされ，1995 年にはミニシンポ ジウム「水生生物に抢けるD型了ミノ酸の分析法, 分 布抢よび生理機能」が開催された。また，甲殼類や二枚
貝の Dーアラニンに関しては細胞内等浸透調節に関与す る主要なオスモライトとしての機能が明らかにされ，嫌 気最終産物としての機能も検討されている。魚類抢よび

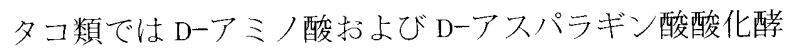
素の存在と性質も調べられている。

魚介類の呈味との関連では, マボヤ, アワビ類, ホタ テガイ, 力キ類, イカ類, 頭足類の墨, シャコ, エビ 類, サケ・マ久類, ウナギ, シマイサキ, ブリ, マサ バ，マダイ，ヒラメ，カッオ・マグロ類，フグ，スッポ ンなど多くの魚介類の工キス成分組成が調べられ，その 季節変化, 成長に伴う変化などが明らかにされてきた。 ホタテガイ, アサリ, タコイカ, イセエビ, ウチワエ ビ，ブリ，イクラ，かつ打節抢よび魚奨油では合成工キ スを用いるオミッションおよびアディションテストによ り呈味有効成分が決定されている。

魚介類の呈味に関する研究では, ブリ筋肉のイノシン 酸の呈味に及ぼす鮮度の影響が調べられている。ズワィ ガニで初めて呈味有効成分とされた無機イオン（ナトリ ウム, カリウム, 塩素, リン酸イオン) は, その後この 20 年間に上記の呈味有効成分が明らかにされたほ上ん どの種で有効成分であることが明らかにされた。一方， 食塩はグリシンとアラニンの甘味を高めることも確認さ れ，食塩はまた苦味と酸味を抑制し，うま味を増強する ことも調べられている。グルタミン酸とスクレオチドの うま味の相乗作用は古くから知られていたが，グリシン などの甘味アミノ酸とイノシン酸が共存すると, うま味 が増強されることが新たに示された。一方，グリシンベ タインの味質が調べられ, 甘味付与効果は弱いものの, 苦味を伴う甘味であることが示された。アルギニンの苦 味はグルタミン酸，アデニル酸および食塩によって抑制 されることも明らかにされた。トリペプチドのグルタチ オンが風味質（厚みおよび持続性）を高めることも調べ られている。その他，これまで呈味成分とはされていな かったゼラチンなどのタンパク質, 脂質およびペプチド 類の魚介類の呈味に及ぼす影響も明らかにされつつある。

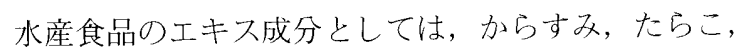
サバ馴れずし，へしこ，イカ塩辛，アユうるか，するめ などのエキス成分組成と製造工程に打ける变化が明らか にされ，最近は未利用資源の有效利用および加工残滓の 利用の観点から, 魚㽜油の工キ又成分に関する研究が多 い。

一万, 1991 年には「魚類に㧍ける死後硬直の生化学 と応用上の諸問題」と題するシンポジウムが開催され, その前後から魚介類エキス成分の貯蔵中の変化に関する 研究が精力的に行われてきた。多くの魚類筇肉の遊離つ ミノ酸，クレアチンリン酸およびヌクレオチドの死後変 化が詳細に明らかにされた。無脊椎動物でもクロアワ ビ, マガキ, イタヤガイ, ホタテガイ, 八マグリ, バ 
イ，イカ，クルマエビ，イセエビ，ロブスター類，ズワ イガニ，マボヤなどのエキス成分の種々の条件下におけ る貯蔵中の変化が調べられている。また, 数種の魚介類 ではあらい，加熱などの調理過程におけるエキス成分の 変化が検討されている。

この 20 年間に魚介類に見出されたエキス成分として は，上記の軟体類のタウロピン (紅藻酸)， $\beta$-アラノピ ン, 無脊椎動物の $\mathrm{D}-ア ミ ノ$ 酸, 魚類の $N$-アセチルヒス チジン，コ一ロッパヒラガキの Dーシステアミドなどが ある。魚類抢よび無脊椎動物のアルセノベタインの分布 が調べられ，マボヤからはハロシニンが単離され，生合 成経路も調べられている。アカガイからは天然では初め てN-メチルーDーアスパラギン酸（NMDA）が発見され た。最近，バフンウニの新規苦味アミノ酸としてプルケ リミンが単離同定されている。

(阿部宏喜)

\section{§5. 酵 素}

この 20 年間の酵素研究において画期的なことは，遺 伝子クローニングによりタンパク質の一次構造の解明が 比較的容易になったことである。この期間でもプロテ ア一ゼを始めとする加水分解酵素に関する研究が多い。

魚介類筋肉の自己消化との関連ではリソゾームのシス テインプロテアーゼであるカテプシンの研究が広範冊に 行われた。カテプシンには多くの種類が知られている が，自己消化への寄与が大きいとされる $\mathrm{B}$ および L 型 は多くの魚類に活性が確認され，性質が明らかにされて いる。シロザケ，マサバ，コイ筋肉などから単離され， 一次構造が明らかにされ, 筋肉タンパク質の分解様式が 検討されている。最近，コイ肝膵臓からカテプシン $\mathrm{S}$ が単離され， $\mathrm{N}$ 末端構造が決められている。一方，中 性プロテアーゼのカルパインはコイ筋肉から精製され,

コイ・ミオシンの分解様式が詳細に検討されている。阻 害タンパク質のカルパスタチンも知られている。火戻り を誘引するアルカリ性プロテイナーゼについても検討が 行われた。筋肉のエキソペプチダーゼではコイ筋肉から ジペプチダーゼ抢よびカテプシン A が精製されている。

消化酵素についても多くの研究が行われてきた。マダ イ, エソ抢よびタラのペプシンとペプシノーゲンが精製 されている。サケ幽門垂とナマズ萃臓からはトリプシン が単離され，ウナギ膵臓のトリプシノーゲンが精製され た。コイ肝膵臓の 2 種のアニオニックトリプシンも単 離され， $\mathrm{N}$ 末端構造が明らかにされている。カタクチ イワシ消化管のトリプシンおよびトリプシノーゲンがク ローニングされ，一次構造が明らかになった。リパーゼ はホタテガイ中腸腺, マダイ肝膵蔵, ティラピア腸管, イカ肝臓などについて検討されている。ホスホリパーゼ $\mathrm{A} 2$ がマダイ肝萃蔵とイトマキヒトデ幽門盲のうからク ローニングされ，ヒトデ類，マダイの鰓执よび幽門垂お
よびコイの肝膵蔵についても検討されている。ティラピ アの腸管抢よび胃から多くの消化酵素類が単離され，性 質が明らかにされている。

コラーゲン执よびエラスチン分解酵素についても検討 が行われている。ナマズ萃臓の両酵素, 魚類幽門重の工 ラスターゼ, クロアワビ, ブリ組織, マイワシ筋肉, 魚 類皮膚のコラゲナ一ゼなどについて検討され，最近では ヒラメ脾蔵，コイおよびニジマスマ細胞外マトリックス からメタロプロテイナーゼ (ゼラチナーゼ) がクローニ ングされている。

キチナーゼの分布が魚類, クラゲ, イカ類, クルマエ ビ組織, シーラカンス胃抢よび海藻類について調ベら れ, 海藻イボッノマタ, スルメイカ肝蔵, クルマエビ肝 膵臓, マダイ胃, ウナギ胃抢よびマサバ胃から単離され ている。一方, 多くの魚類組織打よび軟体類肝蔵の $\beta-$ $N$-アセチルヘキソサミニダーゼの分布も調べられ，ク ラゲ, クルマエビ肝脺蔵, マダコ肝臓抢よびマダイ肝膵 臓から単離されている。コイ血液からは $\beta-N-$ アセチル グルコサミニダーゼも単離されている。一方, 魚類抢よ び貝類のリゾチーム分布が検討され，シジミ類およびア 工体表粘液から単離されている。

ここ10 年ほどの間に, 魚肉の坐りにも関与するトラ ンスグルタミナーゼに関する研究が進展した。貝類，イ 力, エビ，魚類の筋肉と卯などについて活性分布が調べ られた。本酵素は多くの魚類抢よび無脊椎動物について 調べられ, マダイ, スケトウダラ肝臓, マガキ, ホタテ ガイ閉殸筋抢よびイ力鰓から単離されている。

エネルギー代謝関連酵素ではマボヤ，コイ拉よ゙カツ オの筋肉ホスホリラーゼ, コイ筋肉ホスホリラーゼ b キナーゼ，コイおよびニジマスの肝蔵のピルビン酸キ ナーゼとホスホエノールピルビン酸カルボキシキナー ゼ，コイ筋肉乳酸デヒドロゲナーゼ，淡水魚のホスホフ ルクトキナーゼ，ウナギ肝蔵フルクトース-1,6-ビスホ スファターゼ，マガキのグルコースー6-リン酸デヒドロ ゲナーゼ，ホスホリラーゼ抢よびグリコーゲン合成酵 素, 魚類笳肉のヘキソキナーゼ，グリセルアルデヒドー 3ーリン酸デヒドロゲナーゼ（ヒラメからクローニング された)，アルコールデヒドロゲナーゼ，クレアチンキ ナーゼなど多数の研究がある。また，イタヤガイ 3 種 の解糖酵素活性, アコヤガイ解糖酵素の季節変化, コイ 肝膵臓の解糖，糖新生酵素の性質と生理的条件による変 動なども報告されている。

活性酸素消去系の酵素としてはグルタチオンパーオキ シダーゼ, スーパーオキシドジスムターゼ, カタラーゼ が調べられ，カッ才，ヒラメ括よびワムシのスーパーオ キシドジスムター゙は一次構造が判明している。

エキス成分関連酵素としては，タウリン合成系酵素が 単離され，トリメチルアミンオキシドデメチラーゼも精 
製されている。オピンデヒドロゲナーゼ類についても広 く検討され，クロアワビ筋肉にタウロピンデヒドロゲ ナ一ゼが見出され，海綿，セグロイソメ，ヨロイイソギ ンチャクなどから精製され，セグロイソメでは一次構造 も明らかにされている。イノシン酸の生成抢よび分解系 の酵素である AMP デアミナーゼおよび5'スクレオチ ダ一ゼに関する研究も多く, コイやマダイ筋肉から単離 されている。トリプトファン代謝関連酵素についても検 討が行われた。Dーアミノ酸関連では魚類抢よびタコの $\mathrm{D}$ ーアスパラギン酸オキシダーゼと Dーアミノ酸オキシ ダーゼの報告がある。コイ肝膵蔵の D-アミノ酸才キシ ダーゼはクローニングされている。また，ウシエビ筋肉 からアラニンラセマーゼが単離されている。

その他に，マイワシ，アユ抢よびキュウリウオの皮之 紅藻のリポキシゲナーゼについても検討され，アユでは 香気との関連が調べられている。一方, 海洋細菌の各種 多糖分解酵素が明らかにされている。10 年ほど前まで は各種酵素のアイソザイムを分析することによる遺伝的 多型抢よび遺伝距離めるいは地理的变異の研究が多くの 魚種について行われてきたが，最近はミトコンドリア DNA など塩基配列を分析して比較する方法に代わっ ている。

(阿部宏喜)

\section{§6. 色素}

過去 20 年間における色素に関する研究テーマは，力 ロテノイドの構造と代謝, へム色素の自動酸化, その他 (胆汁色素などの色素, 利用加工上の問題の検討など) に大別される。色素については本学会主催のシンポジウ ムでたびたび取り上げられている。ここでは動物および 微生物の色素に関する研究について取りまとめることと し, 海藻の色素については本章「海藻」の項にゆずる。

\section{1 カロテノイドの構造と代謝}

創立 50 周年を迎える少し前（1978 年秋）に本学会主 催のシンポジウム『水産動物のカロテノイド』が開催さ れ，そこでは動物界における分布，代謝抢よび養殖への 応用についての基礎的知見の取りまと女が行われた。そ の後, 1984 年秋の『秋サケの資源と利用』では「ブナ 化上成分変化」というテーマが取り上げられ，シロザケ の遡上に伴うカロテノイドの体内移行と代謝について子 れられている。1985 年春に開催された『水産動物の筋 肉脂質』では「カロテノイド」という項目で, 分子種と 分布, 存在形態などに関して, それまでの研究の流れが まとめらた。さらに，1992 年秋のシンポジウム『海洋 生物のカロテノイド一代謝と生物活性』では, 酸化的打 よび還元的代謝, キサントフィルのビタミン Aへの代 謝, サケの回遊に伴うカロテノイドの移行と代謝などの 新しい知見が盛り込まれた。
この間の研究の流れを辿ると, 魚類ではルテイン, ゼ アキサンチン, アスタキサンチン, ツナキサンチンなど のキサントフィルがプロビタミン Aになり得ること, および eccentric cleavageによってカロテノイドがアポ カロテノイドに代謝されることが確立した。また，ホッ コクアカエビやウシエビに関してはタンパク質複合体の 性状についての検討がなされた。立体構造に関する研究 も精力的に進められ，アスタキサンチンなど単一の成分 と考えられていたものに複数の立体異性体が存在し，そ の組成が生物種と部位により異なることが明らかとなっ た。その後,さまざまな水生生物（海綿動物，軟体動 物, 棘皮動物, 脊索動物など） から数多くの新規カロテ ノイドが単離され，立体構造が決定された。他方，力口 テノイドは一重項酸素, フリーラジカルなどから生体を 保護する機能を果たすことおよび癌細胞増殖抑制活性を 示すことが確認された。

マダイ，ギンザケ，シマアジ，クルマエビなどを中心 に，オキアミ，スピルリナ，酵母などの色素投与による 体色改善と色揚げ後の褪色に関する研究が進められた。 一方，シロザケでは䬶中のアスタキサンチンの大部分は 血清リポタンパク質に結合し，雌ではビテロゲニンにも ある程度結合して血液中を移動し，筋肉，皮执よ゙卵巣 へと移行していくこと，さらに筋肉ではアクトミオシン に結合していることが明らかにされた。同様の研究はギ ンザケについても行われた。

代謝に関する研究も盛んに行われ, 細菌から魚類（ア ユ, ブリ, キンギョ, ティラピア, ブラックバス, カッ オ, マイワシなど), 甲凯類（クルマエビ）, 軟体類（ア ワビ，スクミリンゴガイ）抢よび棘皮動物（ウニ，ナマ コ）に及び，末た還元的代謝の例が数多く報告された。 また，体内代謝を利用した養殖魚の色揚げ，すなわち体 色や肉色の改善, 遮光によるマダイの黒变防止などが試 みられた。そのほか，カッオに打汁るアスタキサンチン の異常蓄積など, 事例研究もいくつか報告された。 1990 年代に入ると, 海綿動物共存細菌の産生する力口 テノイドと炭素資化藻類のカロテノイドに関するものが 見受けられる。海洋細菌のアスタキサンチン合成につい ての研究も行われた。

\section{2 人么色素の自動酸化}

ミオグロビンに関する研究がいくつか報告されている。 1985 年秋のシンポジウム『魚の低温貯蔵と品質評価法』 で「メト化によるマグロの肉色判定法の改良」というテー マで測定精度を上げる万法が紹介されだ。翌年春の『魚 のスーパーチリング』では「マグロ・ミオグロビンの低 温貯蔵中に抢ける色変」というテーマで, 自動酸化速度 と貯蔵温度との関連がまとめられた。さらに，1989年 春開催のシンポジウム『水産動物筋肉タンパク質の比較 生化学』の中の「色素タンパク質」の項では, 動物界に 
おける呼吸色素の分布，ミオグロビンのメト化とその還 元機構, 凍結貯蔵中の自動酸化に及ぼす温度上 $\mathrm{pH}$ の影 響などについてまとめられている。

マグロ肉は褐変防止のため $-50^{\circ} \mathrm{C}$ 以下で保管される こともあったが，省エネルギーの観点から，品質を損な わずに貯蔵温度を上げられる限界，パーシャルフリーシ ングなど氷点付近での自動酸化の進行，などについて研 究がなされた。

\section{3 その他の色素に関する研究}

胆汁色素（ビリベルジン，ビリルビン）の成分組成が ブリ，マダイなど数魚種で確認された。一方，養殖マダ イの黑化現象について, メラニンの定量法の改善上遮光 の有効性が報告されたほか，魚介類（マダイ，キンメダ イ、クルマエビなど）の体色と表皮色素細胞の挙動に影 響する条件の検討がなされた。また，アコヤガイ貝柱， アロツナス筋肉, イ力肝蔵などの色変, 真珠の色調など の事例的研究も散見される。1990 年代に入って, 色素 そのものではないが，紫外線吸収物質に関する研究がい くつか報告された。

(落合芳博)

\section{§7. 生理活性物質}

この 20 年間で，分離技術ならびに機器分析の急速な 進歩々あいまって，水圈生物由来の生理活性物質に関寸 る知見が大幅に集積された。ここでは，本学会会員の研 究成果について概説する。

\section{1 食中毒の原因となる毒}

ツムギハゼから tetrodotoxin（TTX）が分離されて以 来, 様々な生物種にこの毒が検出された。飼育実験の結 果などから，フグはTTXを作らないという仮説が立て られ，“真の生産者”の探索が活発に行われた。その結 果, Alteromonas属, Vibrio 属などのバクテリアが TTXを作ることが明らかにされた。また，フグ肝蔵な どから 11-deoxyTTX を始め数種の新しい誘導体が発 見された。なお，フグのNaチャンネルの構造解析か ら，フグの TTXに対する耐性機構にも光が当てられた。

シガテラの原因が渦鞭毛藻 Gambierdiscus toxicus であ ることが 1977 年に明らかにされ，原因毒である ciguatoxin の解明も間近と思われたが，それには 1989 年まで待たねばならなかった。タヒチ産のドクウッボ 4 トンから純粋に得られた毒 $0.35 \mathrm{mg}$ 在解析して特異な 梯子型ポリエーテル化合物と決定された。この毒は TTXの 100 倍の毒性を走した。引き続き，G. toxicus が生産する maitotoxinの構造が明らかにされた。分子 量 3,422の梯子型ポリエーデ化合物で，毒性はTTX の300 倍であった。この研究成果は 1990 年代の天然物 化学研究に打沙金字塔とい犼る。一方, 東南アジア などで散発するヒロハオウギガ二中毒あるいはニシン中
毒の原因は palytoxin と結論された。なお，渦鞭毛藻 Osteropsis siamensis からこの毒の誘導体が得られた。

麻痺性貝中毒もわが国の各所で散発するようになり, 二枚貝の毒性モニタリングと毒組成の分析が定期的に行 われるようになった。数種の新しい saxitoxin 誘導体が 発見されるとともに，麻痺性貝毒を産生する渦鞭毛藻と 藍藻が新たに見いだされた。1976 年に三陸沿岸で始め て発生した下痢性貝中毒は年とともに大きな問題とな

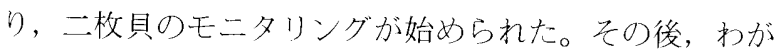
国だけに止まらず全世界的な問題となっている。原因と なる okadaic acid とその誘導体, pectenotoxin 類抢よ び yessotoxin 類が報告されているが，前二者は洞鞭毛 藻 Dinophysis fortii などにより生産される。なお゙,これ らの毒は, 強い発癌プロモーター作用有する。このほ か，神経毒性貝中毒の原因と考えられるbrevetoxin 誘 導体が毒化した二枚貝から報告されている。

\section{2 その他の毒}

魚類の大量撆死を起こす汽水性ハプト藻Prymnesium parvum から, 強い魚毒性老もつ特異なポリエーテル化 合物の prymnesin 類が分離され, 一方Alexandrium hiranoiから魚毒性マクロリド goniodomin-A が得られ た。さらに, grammistin と総称されるぺプチド性の皮 膚毒をもつ一群の魚類のうち，又ノサラシとアゴハタか ら数種の grammistin が分離され，アミノ酸配列が決定 さ机た。

刺毒をもつ海洋生物は多く, 被害も少なくないことか ら，毒の本体の解明が待たれていたが，最近になってア ンドンクラゲ，八ブクラゲおよびウンバチイソギンチャ クの毒のアミノ酸配列と活性が相次いで報告された。な 㧍，数種のイソギンチャク加らペプチド性の毒やプロテ ア一ゼインヒビターが分離された。

\section{3 医薬素材}

1980 年代に入り，抗菌・抗力ビ，抗腫瘍，酵素阻害 など医薬として重要な活性を持つ化合物の探索が王に海 洋無脊椎動物を対象に行われ，これまでに400近くの 新しい活性物質が得られている。抗菌・抗力ビ物質とし ては，海綿から得られた最初の生物活性ペプチドとなっ た discodermin 類在含む多くの化合物が得られている。 なかでも，これまでにないトリスオキサゾールを含むマ クロリドの kabiramide/mycalolide 類は抗力ビ活性が強 く，かつアクチン脱重合作用をもつので注目される。ま た, 強い抗力ビ活性を持つ gambieric acid が G. toxicus 加発見された。抗腫瘍物質としては，13-deoxytedanolide, cinachyrolide $\mathrm{A}$, theopederin 類, ritterazine 類など非常に強い活性をもつものが多く報告され た。これらのうち, 活性が顕著な calyculin A は, タン パク質脱リン酸化酵素 1 型および $2 \mathrm{~A}$ 型の活性中心に結 合して, 酵素活性を強く阻害することが明らかとなり, 
重要な研究ツールとなっている。一方, 抗菌性や抗腫痬 性を赤すタンパク質がアメフラシなどから得られている。

酵素阻害剤のうち，セリンプロテアーゼの阻害剤が最 も多く報告されているが，なかでも cyclotheonamide A が最も注目されている。2つの新しいアミノ酸を含むこ と，抢よび酵素との複合体の結晶構造が明らかにされて いることなどから，抗スロンビン剤開発の有用なモデル 化合物上なっている。なお, 淡水産藍藻から多数のセリ ンプロテアーゼ阻害性のペプチドが報告された。一方, 魚介類笳肉の酵素消化物からアンギオテンシンII变換酵 素阻害活性を有するオリゴペプチドが多数得られた。ま た，グリコシダーゼ阻害率として海綿と海藻から十指に 余る化合物が報告された。このほか，メタロプロテアー ゼ，システインプロテアーゼなどの阻害剤が得られてい る。

レセプターやチャンネルに作用する化合物もいくつか 報告されているが，海綿から発見されたdysiherbaine は選択的なグルタミン酸レセプターアゴニストとして注 目される。

\section{4 その他}

近年, 海洋生物レクチンに関する知見が急速に蓄積さ れて抢り, 比較生化学, 進化生物学あるいは応用の面か ら注目されている。フジッボ, アメフラシ，アナゴなど から得られたレクチンの一次構造と結晶構造が報告され た。一方，海藻は他の生物のもの上は異なるレクチンを 含むので, 今後の展開に興味がもたれる。

一方, TBT（トリブチルスズ）と TBTO（トリブチ ルスブオキシド）に代わる“環境に優しい”防污剤の開 発を目指して海洋無脊椎動物から候補物質の探索が活発 に行われ，多数の防污活性物質が発見された。これらの なかには防污剤開発に向けて試験中のものもある。

(伏谷伸宏)

\section{$\S 8$. 海 藻}

海藻の研究は 1980 年代前半までは食用海藻（ノリ， ワカメ，コンブなど）のタンパク質, 遊離アミノ酸, 脂 質, 光合成色素などの含量, 分布, 貯蔵・加工中の変化 などについて主に行われてきたが，1980年代後半から は游離アミノ酸としてDーアミノ酸と含硫アミノ酸の調 査に加えて，機能性に関する研究が多くなった。

ノリについては養殖段階での光合成色素の減少による 色落ち現象が調べられ，色落ち防止に窒素化合物の添加 が有效であるが，添加時期によって効果に差がでること が明らかにされた。また，乾海苔に5'-AMPデアミ ナーゼが存在し，IMPの生成を行うことが提唱され た。さらに，品質を水分含量で評価する試みもされた。 ノリの収量に大きな影響を与える赤腐れ病の防除のため に, 病原菌遊走子の検出がモノクローナル抗体や PCR
法で可能であることが示されるとともに, 病原菌の細胞 壁溶解酵素が研究された。また, 韓国産赤腐れ病病原菌 が日本の病原菌と生化学的, 生理学的および遺伝学的に 比較研究された。各種海藻のタンパク質組成が葉体とプ ロトプラストの間で比較された。脂肪酸組成とそれに及 ぼす温度の影響, 脂肪酸の de novo 合成, 硫酸の代謝 経路の検討, 酵素多型による品種同定およびDNA フィ ソガープリントやrRNA スモールサブュニットの塩基 配列による系統分類も試みら扎た。专た, 海苔製品保存 中のクロロフィルの変性および遊離アミノ酸と揮発性含 硫化合物の量的变化の研究から, 海苔の保存法として低 温貯蔵あるいは窒素を用いる力法が開発された。焼き海 苔の香気成分と加熱温度との関係，水分活性が香気に及 ぼす影響，産地と価格の異なる海苔の遊離了ミノ酸組成 も調べられた。さらに，焼き海苔製品の変質の一つであ る色戻り現象について, 原因がフィコエリスリンの変性 であることが示された。さらに，海苔の付着珠藻の除去 にタンパク質分解酵素で処理する試みもなされた。

ワカメのタンパク質組成が藻体とプロトプラストとで 比較調查された。加工時に用いられる䣷酸により, 水溶 性多糖の減少と不溶性多糖の増加で藻体は硬化すること が判明した。ワカメ主要成分のアルギン酸は水溶性とア ルカリ可溶性に分けられ, 藻体内の分布上マンスロン酸 とグルロン酸比（M/G 比）も調ベられた。

コンブではタンパク質組成, アミノ酸組成, ヨウ素の 葉体内分布，アルギン酸・マンニト一ル・ミネラルの月 別変化, 窒素代謝などが調ベられ, さらに乾燥コンブの 復水性, だしの溶出抢よびコンブエキスの色調改良のた めにクロロフィル誘導体の研究もなされた。

ヒジキも非極性成分としてステロール，脂肪酸メチル 抢よび炭化水素が調べられたほか，元素の周年変動が検 討された。クロロフィルータンパク質複合体が分離さ れ，色素組成，色素の季節変化なども研究された。

その他の海藻として，ヒトエグサ，アオノリ類抢よび アオサ類のタンパク質組成とアミノ酸組成, アオノリ類 のステロール, 炭化水素, 脂肪酸, フィトール画分の季 節変動, アオサ類の長鎖アルデヒド, アラメのタンパク 質組成とアミノ酸組成, 植食動物に対する化学的防御機 構, 力ジメの耐凍性改善効果, オゴノリの脂肪酸組成, 脂質分子種，赤血球凝集因子抢よび寒天についても研究 が進んだ。

海藻多糖類に関する多くの研究がある。アルギン酸に 関しては日本産の褐藻類 16 種の水溶性アルギン酸とア ル力リ可溶性アルギン酸の収量と $\mathrm{M} / \mathrm{G}$ 比が調査され た。ワカメでは水溶性アルギン酸とアルカリ可溶性アル ギン酸の藻体部位別の分布が調べられ, アルカリ可溶性 アルギン酸が水溶性アルギン酸の約 3 倍市ること, 水 溶性アルギン酸は成実葉に多く, アルカリ可溶性アルギ 
ン酸は中胁の下部に多いこと，水溶性アルギン酸はアル カリ可溶性アルギン酸より $\mathrm{M}$ 含量が多いことなどが判 明した。アルギン酸中の $\mathrm{M} / \mathrm{G}$ 比を短時間で測定するた めの加水分解条件の改良もなされた。一方，養殖が始ま ったマコンブでは $\mathrm{M} / \mathrm{G}$ 比は秋期に向けて夏期の 2 倍に なることが明らかになった。

フコイダンは日本産の褐藻類 21 種類について調査さ れ，数種の画分を含む不均一なものである場合が多いこ とも判った。ガゴメコンブを用いて共存する水溶性アル ギン酸を除去し，精製フコイダンを分別できる方法も検 討された。

カラゲナンは沖縄産カタメンキリンサイで研究され， 分離されたカラゲナンはヒステリシス，凝固点，ゲル融 点，レオロジ一的性質など物理的性状加らはイオタカラ ゲナンに類似するが，赤外吸収スペクトルからはカッ パーカラゲナンに類似していた。

寒天のゲル強度は平均分子量に依存せず，分子量分布 の相違によるゲル構造の違いに影響されることが明らか にされた。日本産のツルシラモからはゲル強度の強い寒 天が $26 \%$ の高収量で抽出され，寒天の新たな主原料之 しての実用性が認如たた。

ポルフィランはナラワスサビノリで調ベられ，藻体か らの抽出条件が検討された。高収量を岕げるためにはホ ルマリン存在下で加熱抽出し, ろ過, 透析抢よびエタ ノール沈殿するとよく，抽出温度が高い上高分子成分が 増加し，抽出時間が長い上低分子成分が増加することも 判った。また，ポルフィラン分解酵素産生細菌が分離さ れ，分解酵素の性質も調べられた。

海藻の機能性に関する研究は精力的に進められた。マ ウ久に緑藻 4 種, 褐藻 24 種および紅藻 28 種を経口投 与し，エールリッヒ腹水癌に対する抗腫瘍活性がスク リーニングされた。腫瘍増殖抑制率で評価すると，特に 活性が強かったものは褐藻力ヤモノリ (69.8\%), Lessonia nigrescens $(60 \%)$, マコンブ $(57.6 \%)$, オオバモ ク $(46.5 \%)$, 紅藻スサビノリ $(53.2 \%)$, Eucheuma gelatinae (52.1\%) 打よび緑藻スジアオノリ (51.7\%) であった。Meth A 繊維芽肉腫に対する抗腫瘍活性は緑 藻 2 種, 褐藻 13 種, 紅藻 9 種について, 腹腔内投与に よってスクリーニングされた。抗腫瘍活性が強かったも のは，ヤツマタモク (55.5\%), オオバモク (39.1\%), ミッイシコンブ $(36.6 \%)$, カジメ $(35.9 \%)$, 紅藻 $E u$ cheuma cottonii (39.8\%) 拉よびツノマタ (34.7\%) で あった。海藻の多糖類と脂質についても抗腫瘍活性が調 べられた。多糖類では褐藻りカメと才オバモクのフコイ ダン画分，カラゲナン拈よびポルフィランが40.1〜 $78.1 \%$ の抗腫瘍活性老示した。脂質画分の抗腫瘍活性 は Meth A 䋐維芽肉腫に対して，才オバモクの中性脂 質，糖脂質抢よびリン脂質が $36.1 \sim 47.1 \%$ ，ミツイシ
コンブの糖脂質上リン脂質が $45.9 \sim 58 \%$ およびスサビ ノリのリン脂質が $64 \%$ を示した。フコイダンの抗腫瘍 活性機構が調べられた結果，フコイダンはマクロファー ジ，細胞障害性 $\mathrm{T}$ 細胞抢よびナチュラルキラー細胞を活 性化するとともに，細胞内皮系を賦活することで宿主の 免疫を増強していることが明らかにされた。また，ポル フィラン由来の硫酸化二糖がマクロフォージの貪食能を 向上させて，抗腫瘍活性を向上させることも調べられた。 血圧低下效果が緑藻 1 種, 褐藻 21 種, 紅藻 4 種打よ び多糖類 6 種についてラットを用いて調查された。拡 張期の吕坐の低下效果は緑藻（ヒトエグサ），褐藻（イ シゲ，オニコンブ，リシリコンブ，マコンブ，カジメ， オオバモク，ジョロモク，マッモ，ウミウチワ）㧍よび 紅藻（スサビノリ，マフノリ，マクサ）で明らかであっ た。海藻の多糖類（ヒトエグサの多糖類，フコイダン， アルギン酸ナトリウム, ポルフィラン，フノラン，寒 天）の血圧低下効果も調べられたが，いずれの多糖類も 效果が明らかであった。フノランを用いて血圧低下の機 構が調ベられ，ラットの尿量の増加に加え，尿中の十卜 リウムの増加とカリウムの減少招よび血中ナトリウムの 減少とカリウムの増加が血圧の低下に重要であると考え られた。また, アマノリとヒジキのタンパク質を酵素分 解して得られたペプチド中に，アンギオテンシンI変換 酵委阻害ペプチドが見出され，構造決定が行われた。

抗高脂血症作用も調查された。緑藻 1 種, 褐藻 21 種 抢よび紅藻 4 種の抗高脂血症作用について，ラットを 用いてスクリーニングが行われた。動脈硬化指数の低下 老指標にすると，ワカメ，才オバモク，マツモ，トゲモ ク，ヤッマタモク，ジョロモク，スサビノリ抢よびマフ ノリが有効であった。多糖類ではヒトエグサの多糖類, アルギン酸とポルフィラン, フノランが有效であった。 ラットを用いてフノランの抗高脂血症の機構が調べら れ，抗高脂血症作用は末端から肝臓へのコレステロール の移動ではなく，粪中への排泄に上るものと考えられ た。ポルフィラン由来の硫酸化オリゴ糖でも血清コレス テロール低下効果が調べられた。

食物繊維の含量が各種海藻で測定され，多くの海藻で は不溶性食物䋐維が水溶性食物繊維より多い傾向にあっ た。また, 針海苔とヒジキでは食物繊維含量の季節変動 が調ベられた。ヒジキ，コンブおよびノリの食物䋐維は 加熱加工処理によって水溶性食物繊維が漸増し，その分 于量は小さくなることが確認された。コンブのアルギン 酸の消化率はラットへの投与期間が長くなるにつれて次 第に上昇し，分子量は初めの $40 \%$ にまで低下するると

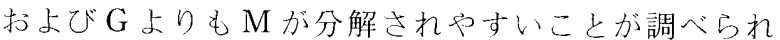
た。食物繊維が吸着する物質も調べられ，ワ力又芽株と ヒジキはチアミンを, ワカメ，マコンブ，ヒジキ打よ゙ スサビノリは抱合型胆汁酸塩をそれぞれ強く吸着した。 
さらに，海藻を超微細化すると，消化率が上昇すること および脂質代謝も改善されることが認められた。

整腸作用については，食用海藻のラット盲腸内フロー ラと血清脂質への影響が調査され，トリグリセリドと遊 離脂肪酸の生合成が抑制されるが盲腸内フローラは海藻 により異なり, 分子量約 50,000の低分子量了ルギン酸 ナトリウムは腸内フローラのバランスを整え, 腐敗物の 生成抑制と腸内環境を整えることが調べられた。

21 種の海藻についてコラーゲン誘発関節炎と皮膚移 植の動物モデルを用いて免疫抑制作用が試験された結果,

11 種の海藻に関節炎発症の抑制作用がみられ，アラ メ，ネジモク，フサカニノテ拈よびオゴノリで強い作用 であった。皮膚移植の拒絶反応に対してはコナハダ属 1 種に強い抑制作用がみられた。海藻は免疫抑制剂として 有望な物質が含まれているとされた。

さらに，海藻レクチン (赤血球凝集素) の研究も進め られた。多くの海藻はウ将やヒッジのプロテアーゼ処 理した赤血球に強い凝集活性をもち，活性の強い海藻は ミル目，スギノリ目抢よびダルス目に集中していた。海 藻レクチンは精タンパク質に直接結合することが特徵で あった。力ギイバラノリのレクチンの一次構造も決定さ れた。

海藻の抗酸化性も調查され，褐藻アラメではフロロタ ンニン類に抗酸化性があり，イシゲでもトコフェロール が量的に多く，抗酸化力が強いとされた。

その他, 海藻の各種酵素関連の研究として, キチン分 解酵素, グリコシダーゼ阻害活性, 血栓溶解酵素の研究 も試みられている。

このような研究が行われた 20 年間に本学会の大会に 扔いて, 海藻の利用, 加工, 化学, 生化学, 生理活性な どに関連する各種のシンポジウムとミニシンポジウムが 開催された。

(天野秀臣)

\section{§9． 細胞生化学}

魚類の株化細胞はニジマス生殖腺由来 RTG-2 細胞が 1962 年に発表されて以来, 100 種類以上細胞株が作 出されている。魚類細胞の多くは魚病ウイルスのバイオ アッセイを行う目的で樹立されたが，近年，生物学およ び生化学の研究材料として幅広く利用されている。魚類 由来株化細胞のほとんどは接着依存性であり，静置単層 培養法によって継代されている。培養の条件と手法は哺 乳類培養細胞々同様である。魚類培貝細胞の特徵は由来 する動物の生理・生化学的特徵に依存する点にある。生 育に必要な培養温度は生物種によって大きく異なってい る。例えば, $\mathrm{RTG}-2$ 細胞の場合, 培養可能な温度域は $4 \sim 24^{\circ} \mathrm{C}$ であり, 生理的な温度域と類似している。

このような細胞生理学的な特徵に着目して，水温など 環境に対する生物応答が魚類細胞を用いて明らかにされ
てきた。ストレス誘導性の一群のタンパク質である熱シ ヨックタンパク質 (heat shock protein, HSP) が, 高温 条件のほか, 重金属, 薬剮, 紫外線, 感染などのストレ ス条件で誘導されることが見出され，細胞レベルでのス トレス条件の解析とその遺伝子発現調節に関する研究が 進められている。また，魚類に特徽的な温度馿化および 浸透圧調節に関する生物応答も培責細胞系を用いて調べ られた。個体レベルの細胞生化学的研究も進展し, コイ 抢よびキンギョの高温馴化誘導性タンパク質 Wap 65 , 低温誘導性のニジマス CDC48, ニジマスフェリチン $\mathrm{H}$ ，コイ ATP 合成酵素抢よびコイ骨格筋ミオシン重鎖 が遺伝子レベルで環境水温によって発現することが明ら かにされた。このような環境への馴化過程において細胞 の分裂，増殖扝よび分化に関わる機能が活発化すること が推定されているが，誘導に関与する分子機構は今後の 課題として残されている。筋分化に関してはMyoD, myf-5, myogenin, MRF4などの転写因子による調節が 同定された。

アポトーシス（プログラム細胞死）の分子機構に関す る研究も近年，大きく発展している。ストレスや薬剤の 刺激を細胞が受けると，アポトーシスを担うカスパーゼ によるカスケード反応が誘発され，細胞死に至る分子機 構が推定されている。

魚類培養細胞系を用いる細胞工学上遺伝子工学に関す 万研究も積極的に進められ，魚類細胞の特徵を活かした ユニークな研究が展開されている。マスノスケ由来 CHSE214 細胞に由来する浮遊培養細胞系が確立され, 魚類細胞をスピナーフラスコ中で高密度培養することも 可能である。エレクトロポレーションによる遺伝子導入 手法が魚類培責細胞への遺伝子導入に用いられており， 効率よく外来遺伝子を魚類細胞に導入・発現させること が可能になった。分子生物学的研究にはクロラムフェニ コールアセチルトランスフェラーゼ (CAT) アッセイ や緑色蛍光タンパク質 (GFP) がレポーターアッセイ に用いられている。初代培養細胞を鯺, 胈, 肝蔵等から 分離し，遊離細胞として培着する技術も多くの魚種で試 みられている。とくにコラーゲン，フィブロネクチンな どの細胞外タンパク質を細胞培養系の基質素材として用 いることにより遊離細胞の接着・伸展を促す手法も取り 入れられている。ウナギ精巣の器官培養系では精原細胞 から精子形成までを人為的に誘導する技術が開発され た。また, 污染物質の毒性評価, エストロゲン様内分泌 攪乱物質の測定など，魚類細胞は水質環境における調査 ・研究にも応用されている。

(山下倫明)

\section{§10. その他}

単純に糖のみを取扱った報告は生理活性物質と海藻関 連でいくつかみられるが，そのほかは本学会ではきわめ 
て少ない。その中では無脊椎動物の酸性ムコ多糖の研究 がある。ナマコ体壁由来の酸性ムコ多糖にはフカン硫酸 とコンドロイチン硫酸の $\mathrm{E}$ 型が結合して抢り，きわめ て硫酸含量が高い。血液清浄作用などの效果が期待され ている。構造までは解析されていないが，その他の海産 無求椎動物由来の酸性ムコ多糖も報告されている。ア才 リイカの包卵腺からはムチンが単離され，コニークな構 造の 4-Oーメチルグルコサミンをもつことが明らかにさ れた。糖に関連する研究として, 中性糖を魚貝類の筋原 繊維に添加してメイラード反応を起こさせ，タンパク質 の溶解度をあげる研究も行われた。

一方，魚類の脂質は 2 重結合に富む高度不飽和脂肪 酸を多く含み，貯蔵中に酸化しやすい。このような魚油 と筋原䋐維タンパク質との反応性が食品的な見地から検 討された。さらに, ウナギは筋細胞に多量の脂質を蓄積 するが，この機構を解明するために，血清中のリポタン パク質の生合成と性状が詳しく検討された。

(渡部終五)

\section{\$11. よ め}

1982 年东での水産の化学・生化学の研究を及ると, 初期には水産物の製造・加工に直接関連したものが多 く，すぐにでも産業に結びっくものが多かった。その 後, 研究は次第に生体成分に関する基礎的研究の方面に も及び, 1983 年以降の現在までの化学・生化学の研究 の礎が築かれた。その原動力となったものは，活きた試
料あるい滈鮮度の研究材料が容易に手に入るようにな ったこと，科学技術の発達により高感度の分析機器が使 えるようになったこと, 遺伝子工学的技術が普及してき たこと，などであろう。このような流れの中で，水産の 化学・生化学の研究では生命科学の色彩が強くなってき た。また, 研究の成果は単に水産学にとよ゙まらず, 医 学, 薬学, 理学, 工学などの他分野へも影響を及ぼすよ うになってきた。逆に, 海洋生物資源の高度利用に当た っては旧来の水産的な技術や方法のみに頼っていては困 難で, 上述した他分野の知識が必要となっている。水産 食品のもつ健康機能性の解明とその利用が一例である。 このように, 水産の化学・生化学の研究はこの20年間 で大きく発展してきたが, 未利用資源も含めた多種多様 な海洋生物について, 構成成分の構造や機能には未だ不 明な点が多く，效果的には利用されていない。研究がさ らに進展してこ玌からどのような新規成分や新しい機能 が発見されるのであ万うかと想像すると興味が尽きな い。化学・生化学の研究で得られた成果を食品のみでな く, 資源, 増殖, 環境などの方面へも利用する方向性も あるう。また，本章でも述べたように，その試みも既に 始末っている。一方, 生命科学の基礎面にばかりに目を 衏秃れていうと, 水産学の本来の大きな目的の一つで ある食料生産とその高度利用の立場を忘れがちになる。 これからの水産の化学・生化学の研究には応用之基礎の バランスのとれた発展が期待される。

(渡部終五) 